Molecules 2005, 10, 105-113

molecules

ISSN 1420-3049

http://www.mdpi.org

\title{
AFM study of a New Carrier Based on PLA and Salen Copolymers for Gene Therapy
}

Véronique Nadeau and Patrice Hildgen*

Laboratoire de Nanotechnologie Pharmaceutique, Faculté de Pharmacie, Université de Montréal, CP 6128, succursale Centre Ville, Montreal, (Québec) H3C 3J7 Canada. Tel.: +1 (514)-6343-6448, Fax: +1 (514) 343-2102.

* Author to whom correspondence should be addressed; e-mail: Patrice.hildgen@umontreal.ca. Received: 18 May 2004 / Accepted: 4 July 2004 / Published: 31 January 2005

\begin{abstract}
The aim of this study was to synthesize novel biodegradable charged polymers to be used in DNA complexation for genetic delivery in different diseases. A new copolymer of PLA and complexed Schiff bases was synthesized in a several steps. This copolymer will be used as a nanocarrier. Also, AFM comparative studies in tapping mode were performed; on cationic copolymer and on PLA-Schiff base copolymer, on non-oriented and oriented film and on the DNA-cationic complex. The results indicated a difference in the topology and on phase picture of AFM film with or without cationic charge.
\end{abstract}

Keywords: AFM, PLA, Genetic Therapy, Vector, Salen, Schiff base.

\section{Introduction}

In genetic disorders, the attempt to replace the faulty or absent gene is known as gene therapy. If successful, this leads to normal working of the cell. Gene therapy is frequently studied in immunotherapy [1], for viral infections [2] and for tissue regeneration [3]. Unfortunately, the unprotected DNA is quickly degraded by the nucleases present in plasma. A lot of obstacles have to be overcome to transport a gene because the targets are inside precise cells. It must be able to pass through the cell membrane, survive intracellular endosomal degradation and finally reach the nucleus of the cell. So, the ideal tool to transport and protect DNA is a non-viral carrier called a polyplex. For example, the strength of the binding between plasmids and polymers yields a collapsed complex that protects nucleic acid against degradation during intracellular transport [4]. Controlling the erosion rate 
of the polymers allows the controlled release of the gene from the carrier. Moreover, polymers present the possibilities to modify the surface of the carrier and to target selective cells [5]. In the present study, we have synthesized new grafted co-polymers based on a polylactide backbone (PLA) to complex DNA. Since atomic force microscopy (AFM), is a powerful tool for semi-quantitative and qualitative measurements on molecular shape and distribution [6], we have performed AFM comparative studies on cationic salen grafted PLA (CS-PLA) and on Shiff's base grafted PLA (SBPLA), on non-oriented or oriented polymer films. Then we used the same method to study the complex of DNA with CS-PLA.

\section{Results and Discussion}

\section{General description}

Because the proposed carriers are made of (cis)-PLA (99\%), they have a potential to mimic the helical structure of DNA and at the same time to ensure the degradation ability of polymer. The remaining $1 \%$ of polymer is allyl glycidyl ether which give pendant arms along the helical PLA. Then, we grafted a Schiff's base complexed to a metal (i.e. cobalt) on the PLA chain to obtain a pendant positive charge. The final macromolecule allows complexation of DNA.

\section{Schiff bases and complex synthesis.}

Schiff's bases were synthesized based on the salicylidene tetradentate ligand derived from 2,5dihydroxybenzaldehyde, salicylaldehyde and diamines. Schiff's base can be readily synthesized based on the method of Larrow and Jacobsen [7] with some modifications to the isolation process. The Schiff base was then complexed with cobalt (Scheme 1). Structures of Salen and complexes were confirmed by ${ }^{1} \mathrm{H}-\mathrm{NMR},{ }^{13} \mathrm{C}-\mathrm{NMR}$, IR and elemental analysis.

Scheme 1. Synthesis of the Schiff base and the complex.
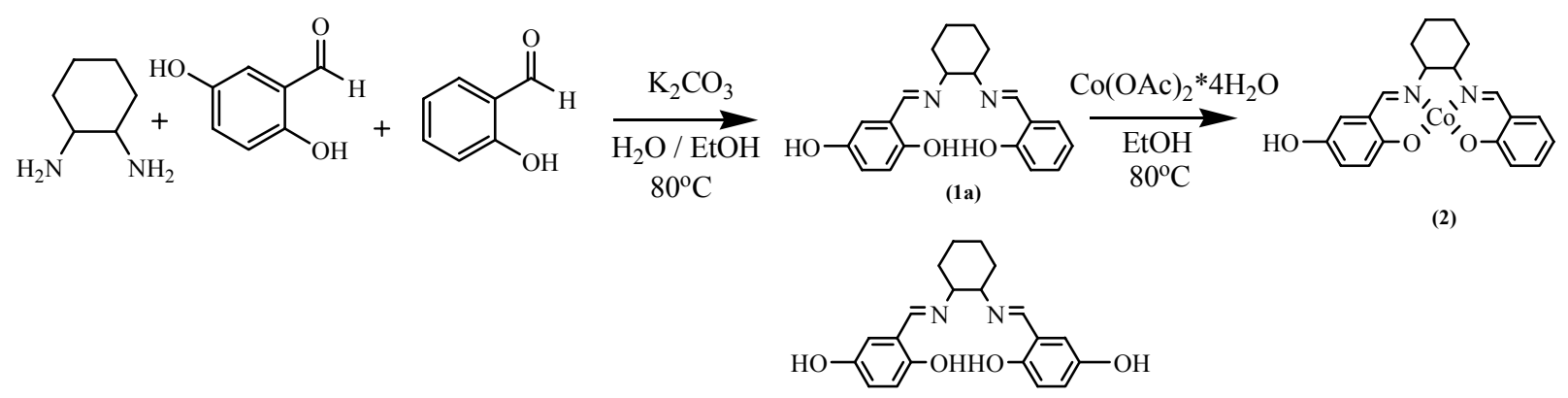

(2)

(1b)

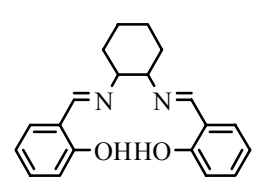

(1C) 
Carrier synthesis based on PLA and salen.

Allyl glycidyl ether was added to the dilactide, obtain PLA with an allyl function, 3 . This epoxide function gets inserted into the polymer during the ring opening polycondensation (Scheme 2). To prevent reaction of the allyl function the polycondensation was done under inert atmosphere (Ar), as the presence of oxygen could initiate a radical polymerization of the allyl function. Moreover, the polycondensation of PLA cannot occur in presence of oxygen or moisture. The polymer $\mathbf{3}$ is an intermediate to have various chemical functions because the allyl function can be easily modified. By hydroboration, a primary alcohol 4 was obtained. By oxidation of alcohol using Jones mixture, the corresponding carboxylic acid 5 was obtained. The latter was converted to the acyl chloride $\mathbf{6}$. Finally the SB-PLA (7) and the CS-PLA (8) were obtained by esterification.

Scheme 2. Synthesis of the PLA and salen copolymer

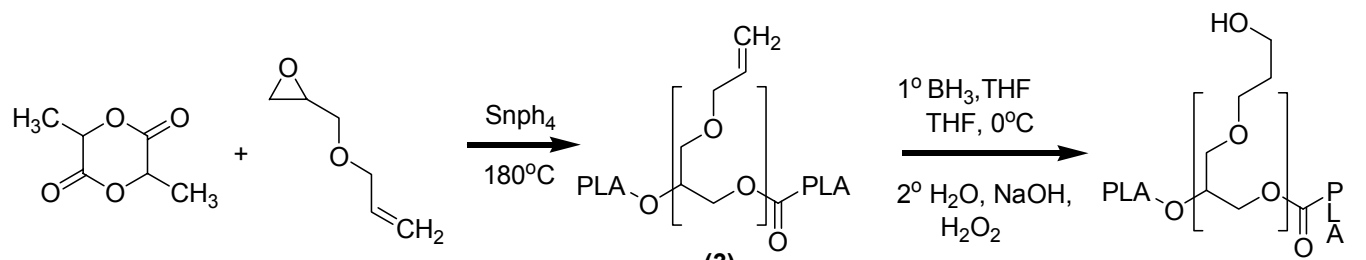

(3)

(4)

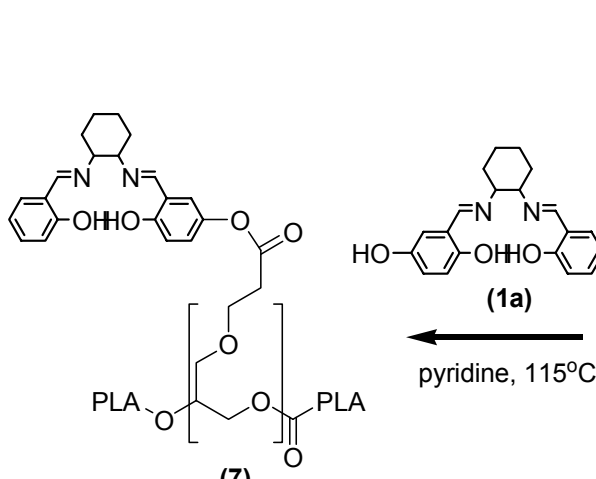

(7)

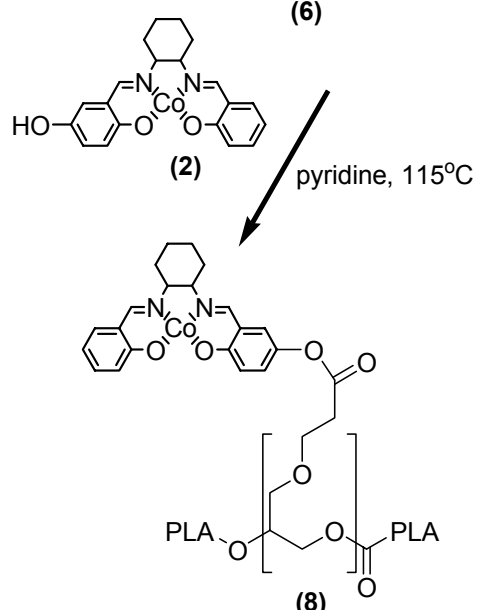

Jones

acetone, $0^{\circ} \mathrm{C}$

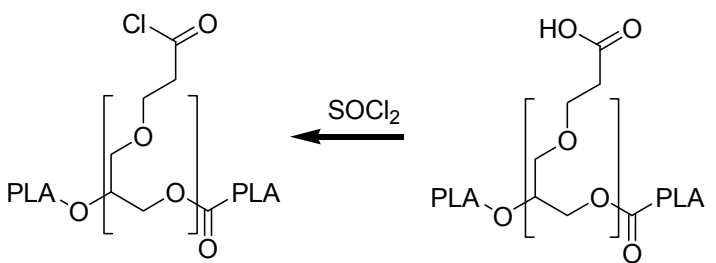

(5) 
AFM study on SB-PLA and CS-PLA non-oriented film.

As shown in Figures 1a and 1c, the topological surface structures respectively of SB-PLA and CSPLA of non-oriented films are different. The organization of SB-PLA looks like spherulitic structures as shown in Figure 1a. Whereas, CS-PLA non-oriented film (Figure 1c) shows a less organized structure than SB-PLA. The presence of cationic metal ions changes the surface organization of polymers.

AFM study CS-PLA non-oriented versus oriented film.

Comparing AFM results for non-oriented CS-PLA films (Figures 1c and 1d) to oriented film (1e and 1f), in topographic mode Figures $1 \mathrm{c}$ and 1e present white toroidal zones on both pictures. In phase mode, the polymer in Figure 1d seems homogeneous, whereas Figure 1f shows an increase of white parts corresponding to a different chemical structure of the heightened part. It is clear that the process drives toroïdal shapes at the interface. This phenomenon is not observed in Figure 1d. As in the oriented film, the arm from allyl glycidyl part was exposed at the surface, the pale zone in Figure $1 \mathrm{f}$ probably represents the arm and complex section with cobalt atom.

AFM study on CS-PLA and SB-PLA oriented film.

Topographic images of CS-PLA and SB-PLA (Figures 1e and 1g) in oriented films show some pale heightened regions. The same structures can be seen in Figures $1 \mathrm{f}$ and $1 \mathrm{~h}$, which show a difference in chemical structure of the surface representing the arm of polymer. Picture $1 \mathrm{f}$ shows some torus with a white center whereas Picture $1 \mathrm{~h}$, in contrast to $1 \mathrm{f}$, shows a black center. This probably can be explained considering that the complexation gives a more rigid structure than a non-complexed Schiff's base. Rigid structure pushes back the AFM probe and appears pale on 1f.

Assuming that the arm groups are oriented on top of the surface as represented by the pale zone on figure $1 \mathrm{j}$, we can calculate how many arms are on oriented CS-PLA. The quantitative analysis gives $1.7 \%$ of pale zone on the total area of the picture. The grafted PLA has $1 \%$ (molar ratio) of arms by synthesis and the volume's ratio is approximately close. The process of orienting the film optimizes the number of arm groups at the surface and tends to increase this percentage. But $1.7 \%$ confirmed that pale zones are the arm on PLA structure.

AFM study on complexed DNA-CS-PLA.

The topography seen in Figures $1 \mathrm{k}$ and $1 \mathrm{~m}$ looks the same except for the size of DNA strands. Topographic shapes seen in Figure $1 \mathrm{~m}$ are bigger $(100-300 \mathrm{~nm})$ than in Figure $1 \mathrm{k}(50-100 \mathrm{~nm})$. the complexing action of CS-PLA on DNA can explain this observation. Using phase mode, we observed that all fragments of DNA strand in Figure 1k are represented by heightened pale zone in Figure 11. The DNA-CS-PLA in phase mode (Figure $1 \mathrm{n}$ ) does not show the same behavior. Each molecular fragment appeared homogeneous in topographic mode (Figure $1 \mathrm{~m}$ ) however in phase mode (Figure 1n) it appeared more heterogeneous, with a mix of dark regions (CS-PLA) and pale regions (DNA). 
We believe that these represents the different chemical structures. This confirms that complexation between DNA and CS-PLA occurred. Moreover an electrophoretic study of the DNA-CS-PLA compare to bulk DNA and polymer demonstrates the complexation of DNA.

Figure 1. AFM study on SB-PLA non-oriented film ( $\mathrm{a}$ in topology and $\mathrm{b}$ in phase mode), CS-PLA non-oriented film (c in topology and $d$ in phase mode), CS-PLA oriented film (e in topology and $\mathrm{f}$ in phase mode), on SB-PLA oriented film ( $\mathrm{g}$ in topology and $\mathrm{h}$ in phase mode), CS-PLA oriented film ( $\mathrm{i}$ in topology and $\mathrm{j}$ in phase mode), on DNA ( $\mathrm{k}$ in topology and 1 in phase mode) and on DNA-CSPLA ( $\mathrm{m}$ in topology and $\mathrm{n}$ in phase mode). Scanning scopes: a. and b. $5 \mu \mathrm{m}$; c. and d. $5 \mu \mathrm{m}$; e. and f. $25 \mu \mathrm{m}$; g. and h. $25 \mu \mathrm{m}$; i. and j. $2 \mu \mathrm{m}$; k. and $1.1 \mu \mathrm{m}$; m. and n. $1 \mu \mathrm{m}$.

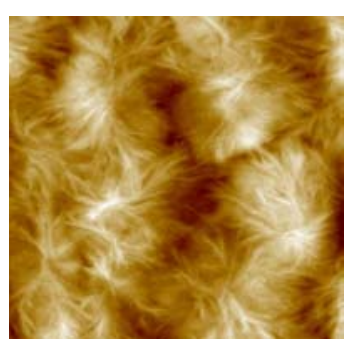

(a)

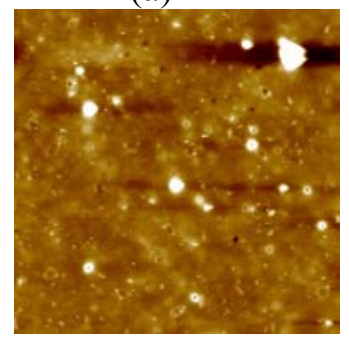

(e)

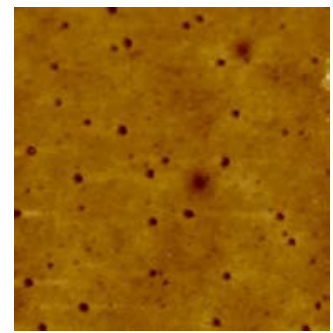

(i)

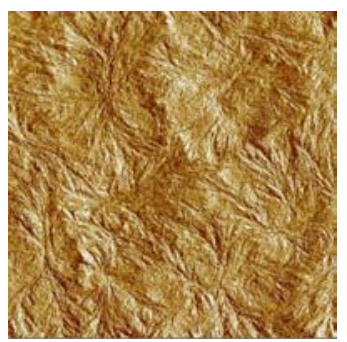

(b)

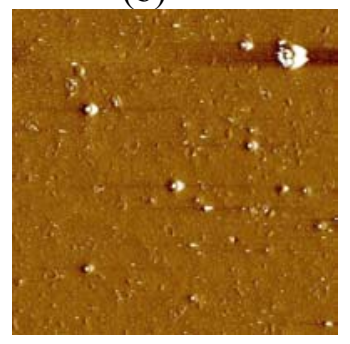

(f)

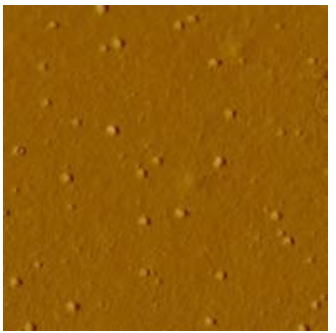

(j)

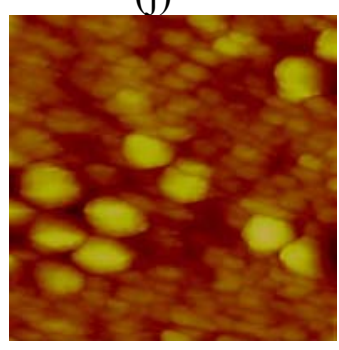

(m)

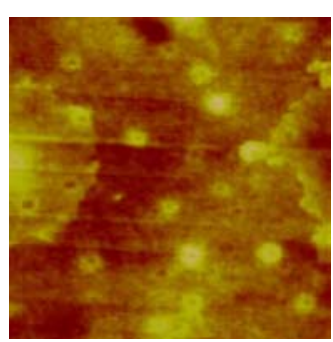

(c)

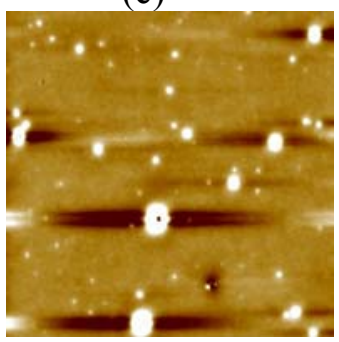

(g)

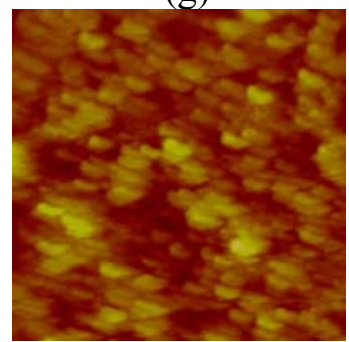

(k)

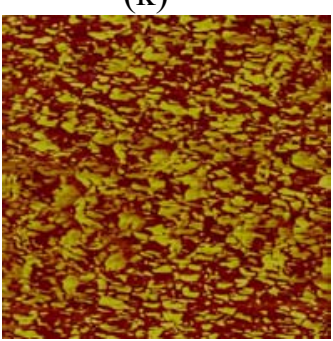

(n)

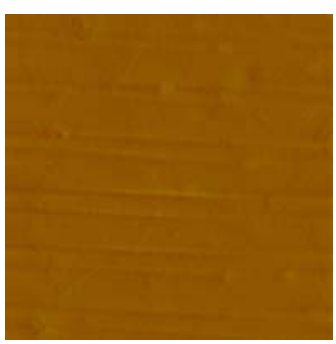

(d)

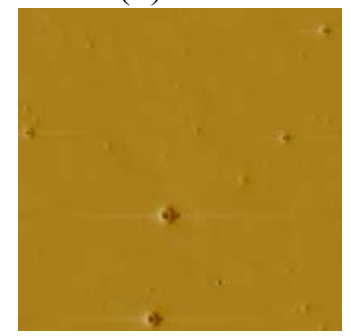

(h)

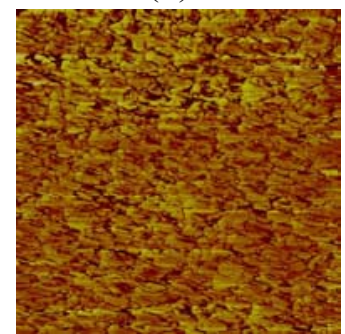

(1) 


\section{Conclusions}

We have presented an easy route for the making a DNA carrier made of PLA and salen. AFM studies on oriented films show differences on arm section of polymers and the PLA part. Finally, the complexation of DNA and CS-PLA are proven by AFM.

\section{Experimental}

\section{General}

All materials (reagents and solvents) were purchased from Laboratoire MAT and Aldrich and used without further purification. Compound characterizations have been performed by ${ }^{1} \mathrm{H}-\mathrm{NMR}$ and ${ }^{13} \mathrm{C}$ NMR using tetramethylsilane (TMS) as an internal standard in $\mathrm{CDCl}_{3}$ on a Brüker $\mathrm{ARX} 400 \mathrm{MHz}$ spectrometer located at the Centre Regional de RMN, by IR-FTIR using a Perkin-Elmer spectrometer, and Elemental analysis was performed by the Laboratoire d'analyse élémentaire of the University of Montreal with a Fisons Instrument, model EA 1108 CHN. The samples were imaged using an AFM Digital Instruments mounted with a Nanoprobe RTESPE7 for mode tapping-air, on mica sheets.

Synthesis of (R,R)-N,N'-bis(2,5-dihydroxysalicylidene)-1,2-diaminocyclohexane (1a). To a solution of potassium carbonate $(7 \mathrm{~g}, 50 \mathrm{mmol})$ and trans-1,2-diaminocyclohexane $(2.6 \mathrm{~mL}, 21 \mathrm{mmol})$ in water $(20 \mathrm{~mL})$ was added ethanol $(65 \mathrm{~mL})$ at room temperature. The resulting mixture was stirred until the reflux temperature $\left(80{ }^{\circ} \mathrm{C}\right)$. A solution of 2,5-dihydroxybenzaldehyde $(2.9 \mathrm{~g}, 21 \mathrm{mmol})$ and salicylidene $(1.7 \mathrm{~mL}, 21 \mathrm{mmol})$ in ethanol $(30 \mathrm{~mL})$ was then added dropwise to the above reaction mixture. Stirring was continued for $14 \mathrm{~h}$ at reflux temperature. After the mixture was cooled to room temperature, the solvent was removed by rotary evaporation. The mixture was extracted four times with ethyl acetate and water. The organic fractions were combined and the solvent was reduced to few milititer by rotary evaporation. Then, this solution was added to hexane $(1 \mathrm{~L})$ to isolate compound 1 a from the two others. The precipitate was collected to yield $1.52 \mathrm{~g}$ of yellow powder (Scheme 1); IR $\left(\mathrm{KBr}, \mathrm{cm}^{-1}\right) 3305,2932,2857,1637,1490,1272,1154,1039,948$ and 794; ${ }^{1} \mathrm{H}-\mathrm{NMR}$ (DMSO-D) $\delta$ (ppm)1.5- 2.0 (m, $8 \mathrm{H},-\mathrm{CH}_{2-}$, cyclohexane), 3.3 (m, $2 \mathrm{H},-\mathrm{CHR}-$, cyclohexane, 6.6 (t, $\left.2 \mathrm{H}, \mathrm{ArH}\right), 6.8$ (d, $2 \mathrm{H}, \operatorname{ArH}), 7.1$ (d, $2 \mathrm{H}, \mathrm{ArH}), 7.2$ (t, $1 \mathrm{H}, \mathrm{ArH}), 8.2$ (s, $2 \mathrm{H},-\mathrm{C} \underline{\mathrm{H}}=\mathrm{N}-)$ ); ${ }^{13} \mathrm{C}-\mathrm{NMR}$ (DMSO-D) $\delta$ (ppm) 25 (- $\mathrm{CH}_{2^{-}}$, cyclohexane), 34 (- $\mathrm{CH}_{2}-\mathrm{CHR}-$, cyclohexane), 73 (- $\mathrm{CH}_{2}-\underline{\mathrm{C} H R}-\mathrm{CHR}-$, cyclohexane), 117.1(CH- $\underline{C H}-\mathrm{C}(\mathrm{OH})$ 1-), 117.4 (CR- $\underline{\mathrm{CH}}-\mathrm{C}(\mathrm{OH})-), 119$ (CH-CHH-C(OH)external-), $121 \quad(-\underline{\mathrm{CR}}=\mathrm{CH}-$ $\mathrm{C}(\mathrm{OH})-), 150(=\underline{\mathrm{C}}(\mathrm{OH}) 5-), 154(=\underline{\mathrm{C}}(\mathrm{OH})$ internal- $)$ and $166(-\mathrm{N}=\underline{\mathrm{CH}}-)$; Elemental analysis calculated: C, 71.2\%; H, 6.3\%; N, 8.3\%. Found: C, 71.3\%; H, 7.0\%; N, 8.7\%.

Synthesis of (R,R)-N,N'-bis(2,5-dihydroxysalicylidene)-1,2-diaminocyclohexane cobalt (2). A reaction flask containing cobalt acetate tetrahydrate $(2.4 \mathrm{~g}, 10 \mathrm{mmol})$ in ethanol $(50 \mathrm{~mL})$ was warmed gently to reflux temperature $\left(80^{\circ} \mathrm{C}\right)$. To this warm solution was added drop wise a solution of 1 (1.1 g, 3.2 $\mathrm{mmol})$ in ethanol $(25 \mathrm{~mL})$. The reaction mixture was stirred and heated at reflux for $14 \mathrm{~h}$. The mixture was then cooled to ambient temperature, and $500 \mathrm{~mL}$ of water is added. The polymer precipitated and was filtered on Büchner to yield 0.94g (74\%) of a red powder (Scheme 1); IR (KBr, cm${ }^{-1}$ ) 3400, 2939, 
2359, 1619, 1548, 1438, 1278, 1213, 1028 and 819; Elemental analysis calculated: C, 60.9\%; H, 4.8\%; N, 7.1\%. Found: C, 60.0\%; H, 5.6\%; N, 5.4\%.

Synthesis of PLA alkene 1\% polymer (3). To remove all water from the regents, the dilactide (21.5 g, $149 \mathrm{mmol})$ and the tetraphenyletin $(7.7 \mathrm{mg}, 0.02 \mathrm{mmol})$ is dissolved in toluene then the solvent was removed by rotary evaporation and the reagents were dried under vacuum in the reaction flask. The glycidyl ether $(0.36 \mathrm{~mL}, 3 \mathrm{mmol})$ was added, warmed and stirred to $180{ }^{\circ} \mathrm{C}$ under argon atmosphere for $6 \mathrm{~h}$. After this, the mixture was cooled to ambient temperature. To wash the gum, the mixture was dissolved in $50 \mathrm{~mL}$ of ethyl acetate and then $100 \mathrm{~mL}$ of water were added. The organic solvent was removed by rotary evaporation and the polymer precipitated in water. The water was thrown out to obtain the polymer. The mixture was washed three times and dried under vacuum to yield $20.8 \mathrm{~g}(95 \%)$ of a white polymer (Scheme 2); ${ }^{1} \mathrm{H}-\mathrm{NMR}\left(\mathrm{CDCl}_{3}\right) \delta(\mathrm{ppm}) 1.5\left(\mathrm{~m}, 3 \mathrm{H}, \mathrm{CH}_{3}\right)$ and $5.2(\mathrm{~m}, 1 \mathrm{H}, \mathrm{CH})$; ${ }^{13} \mathrm{C}-\mathrm{NMR}(\mathrm{DMSO}-\mathrm{D}) \delta(\mathrm{ppm}) 69\left(\mathrm{CH}_{3}\right), 169(\mathrm{CH})$. Elemental analysis calculated: $\mathrm{C}, 50.2 \%$; H, 5.6\%, Found: C, 49.7\%; H, 6.0\%.

Synthesis of PLA alcohol 1\% polymer (4). To dissolve PLA alkene (19.9 g, $2.7 \mathrm{mmol})$, THF (300 mL) was added at $0{ }^{\circ} \mathrm{C}$ then $1 \mathrm{M} \mathrm{NH}_{3}$ in THF $(3 \mathrm{~mL}, 3 \mathrm{mmol})$ was added The mixture was stirred for $2 \mathrm{~h}$ at $0{ }^{\circ} \mathrm{C}$. Then water $(25 \mathrm{~mL}), 3 \mathrm{~N} \mathrm{NaOH}(25 \mathrm{~mL})$ and $\mathrm{H}_{2} \mathrm{O}_{2}(30 \%, 25 \mathrm{~mL})$ were added. After $1 \mathrm{~h}$, water $(300 \mathrm{~mL})$ was added. The solvent was removed by rotary evaporation, then the precipitate was washed using the same method described for 3 . The polymer is dried under vacuum to give $14.9 \mathrm{~g}(75 \%)$ of a white polymer (Scheme 2); ${ }^{1} \mathrm{H}-\mathrm{NMR}\left(\mathrm{CDCl}_{3}\right) \delta(\mathrm{ppm}) 1.5\left(\mathrm{~m}, 3 \mathrm{H}, \mathrm{CH}_{3}\right)$ and $5.2(\mathrm{~m}, 1 \mathrm{H}, \mathrm{CH})$; ${ }^{13} \mathrm{C}-\mathrm{NMR}$ (DMSO-D) $\delta$ (ppm) 69, 169; Elemental analysis calculated: C, 50\%; H, 5.6\%, Found: C, $49.4 \% ; \mathrm{H}, 5.8 \%$.

Synthesis of PLA acid 1\% polymer (5). To dissolve 4 (8.4 g, $1.15 \mathrm{mmol})$, THF (500 mL) was added at $0{ }^{\circ} \mathrm{C}$. Then Jones mixture: $\mathrm{CrO}_{3}(0.23 \mathrm{~g}, 2.30 \mathrm{mmol}), \mathrm{H}_{2} \mathrm{SO}_{4}(0.23 \mathrm{~mL})$ and water $(0.70 \mathrm{~mL})$ was added in this order. The mixture is stirred for $3 \mathrm{~h}$ at $0{ }^{\circ} \mathrm{C}$ then isopropyl alcohol $(30 \mathrm{~mL})$ and $\mathrm{HCl}(1 \mathrm{~N}, 500$ $\mathrm{mL})$ were added. The solvent is removed by rotary evaporation. The precipitate was washed as described for 3. The polymer is dried under vacuum to give $7.8 \mathrm{~g}(93 \%)$ of white polymer (Scheme 2); ${ }^{1} \mathrm{H}-\mathrm{NMR}\left(\mathrm{CDCl}_{3}\right) \delta(\mathrm{ppm}) 1.5\left(\mathrm{~m}, 3 \mathrm{H}, \mathrm{CH}_{3}\right)$ and $5.2(\mathrm{~m}, 1 \mathrm{H}, \mathrm{CH}) ;{ }^{13} \mathrm{C}-\mathrm{NMR}$ (DMSO-D) $\delta(\mathrm{ppm}) 70$ $\left(\mathrm{CH}_{3}\right), 169(\mathrm{CH})$; Elemental analysis calculated: $\mathrm{C}, 50 \%$; H, 5.6\%, Found: $\mathrm{C}, 49.5 \%$;, $6.0 \%$.

Synthesis of PLA acyl chloride 1\% polymer (6). A reaction flask containing 5 (2 g, $0.27 \mathrm{mmol})$ in $\mathrm{SOCL}_{2}(25 \mathrm{~mL})$ is stirred at ambient temperature for $2 \mathrm{~h}$. After this time, the solvent is removed by rotary evaporation. The precipitate is collected to give $1.23 \mathrm{~g}(61 \%)$ of white polymer (Scheme 2); IR $\left(\mathrm{KBr}, \mathrm{cm}^{-1}\right) 3050,1750,1454,1363,1350,1225,1100$ and $867 ;{ }^{1} \mathrm{H}-\mathrm{NMR}\left(\mathrm{CDCl}_{3}\right) \delta(\mathrm{ppm}) 1.5(\mathrm{~m}, 3$ $\left.\mathrm{H}, \mathrm{CH}_{3}\right)$ and $5.2(\mathrm{~m}, 1 \mathrm{H}, \mathrm{CH}) ;{ }^{13} \mathrm{C}-\mathrm{NMR}$ (DMSO-D) $\delta(\mathrm{ppm}) 69\left(\mathrm{CH}_{3}\right), 169(\mathrm{CH})$; Elemental analysis calculated: C, 49.8\%; H, 5.6\%, Found: C, 51.1\%; H, 5.9\%.

Synthesis of PLA-(R,R)-N,N'-bis(2,5-dihydroxysalicylidene)-1,2-diaminocyclohexane polymer (7). A reaction flask containing $1 \mathrm{a}(3 \mathrm{mg}, 0.009 \mathrm{mmol})$ and $\mathbf{6}(1.5 \mathrm{~g}, 0.2 \mathrm{mmol})$ in pyridine $(20 \mathrm{~mL})$ is stirred and warmed gently to reflux $\left(115{ }^{\circ} \mathrm{C}\right)$ for $3 \mathrm{~h}$. After this time, the mixture is cooled to ambient 
temperature. To the mixture was added water $(50 \mathrm{~mL})$. The precipitated polymer is filtered and collected to give $1.5 \mathrm{~g}(99 \%)$ of white polymer (Scheme 2); IR (KBr, cm $\left.{ }^{-1}\right) 3000.2980,1750,1600$, 1450, 1369, 1200, 1188, 1085 and 866; ${ }^{1} \mathrm{H}-\mathrm{NMR}\left(\mathrm{CDCl}_{3}\right) \delta(\mathrm{ppm}) 1.5\left(\mathrm{~m}, 3 \mathrm{H}, \mathrm{CH}_{3}\right)$ and $5.2(\mathrm{~m}, 1 \mathrm{H}$, $\mathrm{CH}) ;{ }^{13} \mathrm{C}-\mathrm{NMR}$ (DMSO-D) $\delta(\mathrm{ppm}) 70\left(\mathrm{CH}_{3}\right), 169(\mathrm{CH})$.

Synthesis of PLA-(R,R)-N,N'-bis(2,5-dihydroxysalicylidene)-1,2-diaminocyclohexane cobalt polymer (8) . A reaction flask containing $2(209 \mathrm{mg}, 0.5 \mathrm{mmol})$ and $6(1.9 \mathrm{~g}, 0.3 \mathrm{mmol})$ in pyridine $(20 \mathrm{~mL})$ is stirred and warmed gently to reflux $\left(115{ }^{\circ} \mathrm{C}\right)$ for $2 \mathrm{~h}$. After $2 \mathrm{~h}$, the mixture is cooled to ambient temperature. To the mixture is added water $(50 \mathrm{~mL})$. The precipitated polymer is filtered and collected to give $1.5 \mathrm{~g}(74 \%)$ of beige polymer (Scheme 2); IR (KBr, $\left.\mathrm{cm}^{-1}\right)$ 3000. 2980, 1750, 1600, 1450, 1369, 1200, 1188, 1085 and 866; ${ }^{1} \mathrm{H}-\mathrm{NMR}\left(\mathrm{CDCl}_{3}\right) \delta(\mathrm{ppm}) 1.5\left(\mathrm{~m}, 3 \mathrm{H}, \mathrm{CH}_{3}\right)$ and $5.2(\mathrm{~m}, 1 \mathrm{H}, \mathrm{CH})$; ${ }^{13} \mathrm{C}-\mathrm{NMR}$ (DMSO-D) $\delta(\mathrm{ppm}) 70\left(\mathrm{CH}_{3}\right), 169(\mathrm{CH})$; Elemental analysis calculated: $\mathrm{C}, 50.5 \%$; H, 5.5\%; N, $0.3 \%$. Found: C, 49.1\%; H, 5.8\%; N, 0.2\%.

AFM study. AFM was performed on CS-PLA (8) and on SB-PLA (7), on not oriented and oriented film and on the DNA-CS-PLA complex. To obtain a non-oriented film: dissolve the polymer $(0.1 \mathrm{~g})$ with chloroform $(5 \mathrm{~mL})$. Place a drop of the polymer solution on mica and wait until complete evaporation of solvent. To obtain an oriented film: dissolve the polymer $(0.1 \mathrm{~g})$ in chloroform $(5 \mathrm{~mL})$ and add water $(5 \mathrm{~mL})$ to the polymer solution. At this step, we observe a film at the interface of both layers. Cautiously get the film with the mica sheet to obtain the grafted hydrophilic part on top.

AFM study of DNA complexed to cationic polymer. Add calf thymus DNA (0.01 g), having a high polymeric weight, to $400 \mathrm{mM}$ ammonium acetate $(50 \mathrm{~mL})$ and $10 \mathrm{mM}$ of $\mathrm{MgCl}_{2}(50 \mathrm{~mL})$. Adjust the $\mathrm{pH}$ to 7.0 with $\mathrm{NaOH}$. Put a drop of this solution on mica sheet and dry it in oven for 50 minutes. Wash the mica sheet, dip it in a mixture of 50:50 water-ethanol three times then in $100 \%$ ethanol to remove salt. Dry it before AFM testing.

Complexing DNA with cationic polymer. Dissolve cationic polymer $(0.1 \mathrm{~g})$ in chloroform $(5 \mathrm{~mL})$. Take DNA solution $(2 \mathrm{~mL})$, adjust to $\mathrm{pH} 7.0$ as before and add cationic polymer $(2 \mathrm{~mL})$. The resulting solution was vortexed for two minutes and a drop was deposited on a mica sheet. The sample was dried before AFM testing.

\section{References}

1. Vile, R. G.; Russell, S. J.; Lemoine, N. R. Cancer gene therapy: hard lessons and new courses. Gene. Ther. 2000, 2-8.

2. Okuda, K.; Ihata, A.; Watabe, S.; Okada, E.; Yamakawa, T.; Hamajima, K.; Yang, J.; Ishii, N.; Nakazawa, M.; Okuda, K.; Ohnari, K.; Nakajima, K.; Xin, K. Q. Protective immunity against influenza A virus induced by immunization with DNA plasmid containing influenza $\mathrm{M}$ gene. Vaccine 2001, 9, 3681-3691.

3. Bonadio, J.; Smiley, E.; Patil, P.; Goldstein, S. Localized, direct plasmid gene delivery in vivo: prolonged therapy results in reproducible tissues regeneration. Nat. Med. 1999, 5, 753-759. 
4. Dunlap, D. D.; Maggi, A.; Soria, M. R. Nanoscopic structure of DNA condensed for gene delivery. Nuc. Acids Res. 1997, 25, 3095-3101.

5. Cotton, M.; Wagner, E. (1993). Nonviral approaches to gene therapy. Curr. Opin. Biotech. 1993, 4, 705-710.

6. Martin, L. Bennink; Dessy, N. Nikova; Kes O. Van Der Werf; Jan G. Dynamic imaging of single DNA-protein interactions using atomic force microscopy. Anal. Chim. Acta 2002, 479, 3-15.

7. Larrow, J. F.; Jacobsen, E. N. A practical method for the large-scale preparation of N,N'-Bis (3,5di-tert-butylsalicylidene) 1,2-cyclohexanediaminato (2-) manganese(3) chloride, a highly enantioselective epoxidation catalyst. J. Org. Chem. 1994, 59, 1939-1942.

(C) 2005 by MDPI (http://www.mdpi.org). Reproduction is permitted for noncommercial purposes. 